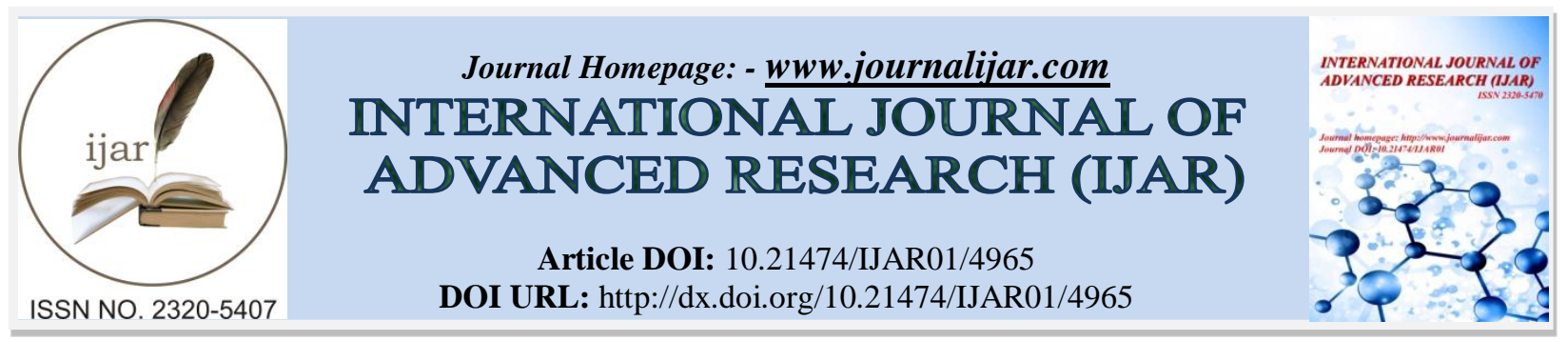

RESEARCH ARTICLE

\title{
PROBIOTICS ON SURVIVAL, GROWTH AND SELECTED IMMUNE FUNCTIONS OF PACIFIC WHITE SHRIMP LITOPENAEUS VANNAMEI UNDER DIFFERENT FEED FORMULATIONS IN ANDHRA PRADESH, INDIA.
}

\author{
V. Hemanth Kumar and "P. V. Krishna.
}

Department of Zoology \& Aquaculture, Acharya Nagarjuna University Nagarjuna Nagar-522510, A.P, India.

\section{Manuscript Info} .

\section{Manuscript History}

Received: 26 May 2017

Final Accepted: 28 June 2017

Published: July 2017

Key words:-

Litopenaeus vannamei, Probiotics, Survival and Production, Immunity.

\section{Abstract}

Pacific white shrimp Litopenaeus vannamei is one the most intensively cultivated shrimp in India as well as world. The recent experience in the development of large scale aquaculture venture has given rise to the opinion that the key to success in not the availability of adequate technology, but also efficient management. The present study reported that Litopenaeus vannamei in the brackish water shrimp ponds in Nellore, Andhra Pradesh, India. The study was conducted in three culture ponds (without probiotics) P1, P2, P3 and ponds (with probiotics) P1p, P2p and P3p of same size i.e. 0.5ha. The control ponds fed with experimental feed F1, F2 and F3 and the experimental ponds with soil, water and feed probiotics respectively. Feeding was done four times a day. The physico-chemical parameters were analyzed using standard methods. The rate of survival was better recorded in the probiotics treated ponds $84.5 \%, 80.4 \%$ and $79.8 \%$ than that of the non-probiotic ponds it is $73.4 \%, 69.8 \%$ and $67.5 \%$ only. The study observed the increased level of growth, production, survival and feed conversion ratio during the culture period. The results of the present study also revealed that the total haemocyte count and the total haemolymph protein were higher in probiotic fed Litopenaeus vannamei compared to without probiotic fed shrimp.

Copy Right, IJAR, 2017,. All rights reserved.

\section{Introduction:-}

Shrimp aquaculture sector occupies very important role in the socio-economic development of the country and also provided proteinaceous food for poor people. The issue of malnutrition has become important for the growing population in India as well as world. The pacific white shrimp Litopenaeus vannamei has become the main crustacean species produced through culture, with production exceeding that of black tiger shrimp Penaeus monodon since 2003 (FAO, 2007). It is highly technical activity and sensitivity to the environment. Indiscriminate and unplanned use of feed and fertilizers with subsequent effects on water quality in pond ecosystems and correspondingly increases stress on shrimp and accelerate susceptibility to pathogen. The concept of sustainability serves as a tool for evaluating the more sustainable product, a farm raised shrimp or a wild caught shrimp. Determining which product is more sustainable relies on the knowledge of how the shrimp caught or how the shrimp was raised. At present $L$. vannamei provides a significant contribution to the total value of Aquaculture production in India and also several parts of the world (Wurmann et al., 2004). The momentum of growth in Aquaculture acquired in India during late eighties and early nineties started declining due to various bio-physical and socio- 
economic factors including occurrence of white spot syndrome virus (WSSV), stipulations of supreme court and lack of Institutional credit support. It is possible to solve most of the production constituents through well developed management practices. Hence, there is a strong need to facilitate the adoption of Better Management Practices (BMPs) to achieve the goal of sustainable shrimp farming. One of the principles of BMPs includes the usage of probiotics of different types during the culture operation of candidate species in order to increase productivity in the hygienic environment. Probiotics are live non-pathogenic microorganisms that provide colonization resistance to the pathogenic microbes and thus are effective in prevention and treatment of some diseases. Fuller (1992) defined probiotics as live microbial feed supplements, which beneficially affect the host by improving its intestinal microbial balance. Probiotics, including Lactic acid bacteria and Bacillus sp. can be introduced into the culture environment as 'Bio-friendly agents' to control the pathogenic organisms. The use of preventive and environmentally friendly approaches, namely Antibacterial peptides, probiotics and prebiotics are becoming increasingly important in aquaculture, particularly in light of new trends toward organic production systems (Decamp et al., 2008).

In India the aquaculture shrimp health management was regulated with application of several antibiotics, pesticides and disinfectants for controlling of diseases. This application caused the evolution and spreading of drug resistant strains of pathogenic bacteria resulted negative impact on the environment and risk for shrimp health. In recent years biological control of the diseases affecting aquaculture species especially bacteriological disorders including environmentally friendly methods such as use of probiotics has developed and got rich importance in the shrimp health management (Gatesoupe, 1999; Varshurere et al., 2000; Irianto and Austin, 2002; Vine et al., 2006). The results of the studies carried out globally, have included that some of the bacteria used in probiotics (Lactobacillus sp) are capable of stimulating the immune system (Fuller, 1992).

Probiotics in aquaculture is relatively recent and widely administrated to modify and manipulate selected microbial populations in the pond environment and to reduce or eliminate selected pathogens and leading to better survival of the culture species (Irianto and Austin, 2002). The newest attempt to improve water quality in aquaculture is the application of probiotics to ponds. This approach of biotechnology is also known as bioremediation, which involves manipulation of microorganisms in ponds to enhance mineralization of organic matter and get rid of undesirable waste compounds. The concept of biological disease control, particularly using microbiological modulator for disease prevention has received widespread attention (Karthik et al., 2016). The application of probiotics in shrimp benefited the improvement of the intestinal microbial balance, enhancement of the disease resistance by suppressing the pathogens and also the enhancement in the immunity or improvement of water quality by the decomposition of organic matter, reduction in nitrogen and phosphorus concentrations for controlling of ammonia, nitrite and hydrogen sulfide levels (Verschurere et al., 2000). Probiotics usage in the shrimp ponds improve the water quality and improve the animal health (Fuller, 1989; Wang et al., 2005; Vine et al., 2006; Wang, 2007; Balcazar et al., 2006), production of inhibitory compounds (Biomin, 2009) and enhancement of the immune response against pathogenic bacteria. Other benefits include improvement of Feed Conversion Ratio (FCR), Specific Growth Rate (SGR) and protein efficiency ratio (Marrifield et al., 2010). Lower incidence of diseases, greater survival and increase in both shrimp \& fish production were observed in the ponds (Boyd and Massaaut, 1999; Verschurere et al., 2000). Hence, this study was aimed to evaluate the effect of probiotic supplemented diet on growth, survival and haemato-immunological parameters of the shrimp Litopenaeus vannamei.

\section{Materials and Methods:-}

In the present study post larvae of Litopenaeus vannamei were collected from the hatchery at (Cp aquaculture Ltd) Chennai, Tamil Nadu. The average larvae size goes $0.67 \mathrm{~g}$ and in healthy condition. The control ponds P1, P2 and P3 were fed with experimental feed F1, F2 and F3 and ponds P1p, P2p and P3p were treated with soil probiotics (Super Ps) 10 liter water probiotics (Super-biotic) $5 \mathrm{~kg}$ and Feed probiotics (Probi-zyme) $10 \mathrm{~g} / \mathrm{kg}$. All experimental and control ponds were equal in size of 0.5ha. Post larvae were confirmed negative for the White spot syndrome virus (WSSV) and Taura syndrome virus (TSV) through Polymerase Chain Reaction (PCR assay) before packing to farm site oxygenated double layered polyethylene bags. Initial stocking was done at early hours in order to avoid temperature stress. Before stocking, all the bags were kept in the pond water for a period to adjust with the pond temperature. After the completion of acclimatization post larvae were released into the ponds. Prior to stocking all the ponds were dried, tilled and limed for allowing the oxidation and mineralization of organic matter.

Liming was done with Quick lime and Dolamite at 1.5 ton/ha and 1 ton/ha respectively. Inorganic fertilizers such as urea $(5 \mathrm{~kg})$ and triple superphosphate $(20 \mathrm{~kg})$ were mixed and applied. Canal water is pumped to all the ponds with 
the help of motors. Inlets and outlets were provided with filter bags to prevent the entry of predators and other larval species during pumping. Crab fencing and bird netting were used to prohibit the autoentrant around the ponds. Fertilization with cow dung initially and after fertilizers such as urea triple superphosphate mixer. Chlorination was made to all the ponds before stocking the ponds.

In the experimental feed one is commercial feed1 (F1), animal protein as feed2 (F2) and plant protein as feed3 (F3) respectively. Feeding was done four times daily at $6 \mathrm{am}, 10 \mathrm{am}, 3 \mathrm{pm}$ and $7 \mathrm{pm}$ respectively. Check trays (8) were used to observe the feed consumption status. Sampling was done fifteen days through seine net for first $15 \mathrm{days}$ and cast net for the remaining culture period. Weekly analysis of physico-chemical parameters for ponds was carried out using standard methods (APHA, 1985). Field test instruments were used to analyze water pH (Digital mini-pH meter, model 55), Temperature and dissolved oxygen (YSI-58), Transparency (Sacchidisc, Boyd, 1990) Total ammonia (APHA, 1985), Nitrate- Nitrogen (Boyd, 1984), Total alkalinity \& Hardness (APHA, 1985) and Phosphorus (model 21D).

Growth performance was studied by the estimation of growth parameters for every fifteen days. Average Daily Growth (ADG), Specific Growth Rate (SGR), Final weight gain \%, Survival rate \%, Feed Conversion Ratio (FCR) and Total yield $(\mathrm{kg})$ were calculated. Growth parameters were statistically analyzed (ANOVA). Immunological studies such as haemocyte count, phenol oxidize activity and total haemolymph proteins were carried at the end of the experiment for knowing the influence of probiotics treatment on shrimp growth. All the results were analyzed statistically.

\section{Growth Parameters:-}
a. Average Daily Gain $(\mathrm{g})(\mathrm{ADG})=$
Final weight $(\mathrm{g})$

\begin{tabular}{|c|c|c|c|}
\hline \multirow{2}{*}{ a. } & \multicolumn{3}{|r|}{ Final weight (g) } \\
\hline & \multicolumn{3}{|r|}{ Duration of culture (Days) } \\
\hline \multirow{2}{*}{ b. } & \multirow{2}{*}{ Final Weight Gain \% } & \multirow{2}{*}{$=$} & Final weight $(\mathrm{g})$ - Initial weight $(\mathrm{g})$ \\
\hline & & & Initial weight $(\mathrm{g})$ \\
\hline \multirow{3}{*}{ c. } & \multirow{3}{*}{ Specific Growth Rate } & & (Final Weight $(\mathrm{g}))$ - In (Initial Weight $(\mathrm{g}))$ \\
\hline & & & - 100 \\
\hline & & & Duration of culture (Days) \\
\hline \multirow[b]{2}{*}{ d. } & \multirow[b]{2}{*}{ Survival Rate \% } & \multirow[b]{2}{*}{$=$} & No: of Shrimp harvested \\
\hline & & & No: of Shrimp stocked \\
\hline \multirow[b]{2}{*}{ e. } & \multirow[b]{2}{*}{ Feed Conversion Ratio (FCR) } & \multirow[b]{2}{*}{$=$} & Total Feed fed (Dry. wt) (kg) \\
\hline & & & Total Yield (kg) \\
\hline
\end{tabular}

\section{Results and Discussion:-}

In the present investigation, three experimental feeds were selected, i.e. one CP Brand experimental feed, the other two experimental feeds was formulated, one with Animal based ingredients (F2) and the other with Plant based ingredients (F3). The composition of the experimental feeds formulated was presented in Tables 1 \& 2 and the proximate compositions of the experimental feeds were given in Table 3. The growth rates of pacific white shrimp L. vannamei was monitored after a culture period of 120 days. The growth performance with experimental feeds and the average growth values were given in Tables $4 \& 5$. In the present investigation six ponds were stocked with PLs of L. vannamei and were fed with one commercial feed (CP Brand) and two formulated feeds i.e. one feed formulated with animal based ingredients(P1,P2 and P3). The other three ponds were broadcasted with above mentioned feeds along with probiotic treatments (P1p, P2p and P3p). The probiotics selected in the present investigation i.e super PS, super Biotic and UB probiozyme represents, Soil, Water and Feed probiotics respectively. Shrimp were harvested after completion of 120 days of culture operation. One third of water from each pond was drained through outlet just before catching. While two third of water let out, the shrimp were collected and handpicked. Shrimps were immediately transferred to changing tubes provided near the pond. They were rinsed and 
chilled before packing. Random samples were collected during the weighing process for determination of individual weight. After quantifying the biomass, mean final yield, feed conversion ratio, and survival were calculated. Specific growth rates, average daily growth and final weight $\%$ were determined by using the standard formulae.

Table 1:- Animal based ingredients of feed2 (F2)

\begin{tabular}{|c|c|}
\hline Ingredient & Percentage \\
\hline Squilla meal & $28.50 \%$ \\
\hline Shrimp meal & $27.60 \%$ \\
\hline Chicken Liver & $21.50 \%$ \\
\hline Snail foot & $13.86 \%$ \\
\hline Earth warm meal & $11.86 \%$ \\
\hline Vitamin \& mineral mix & $2.40 \%$ \\
\hline Cholestrol & $1.20 \%$ \\
\hline
\end{tabular}

Table 2:- Plant based ingredients of feed3 (F3)

\begin{tabular}{|c|c|}
\hline Ingredient & Percentage \\
\hline Ground nut cake & $35 \%$ \\
\hline Heated Soya bean & $22.70 \%$ \\
\hline Corn gluten & $15.20 \%$ \\
\hline pea meal & $8.50 \%$ \\
\hline Rice bran & $8.20 \%$ \\
\hline Wheat flour & $4.50 \%$ \\
\hline Corn starch & $0.9 \%$ \\
\hline Vitamin \& mineral mix & $2.80 \%$ \\
\hline Soya oil & $1.30 \%$ \\
\hline Cholesterol & $0.90 \%$ \\
\hline
\end{tabular}

Table 3:- Proximate composition of experimental feeds

\begin{tabular}{|c|c|c|c|}
\hline Nutrients & $\begin{array}{c}\text { Feed (F1) } \\
\text { (commercial) }\end{array}$ & $\begin{array}{c}\text { Feed (F2) } \\
\text { (Animal based) }\end{array}$ & $\begin{array}{c}\text { Feed (F3) } \\
\text { (plant based) }\end{array}$ \\
\hline Crude protein & $37.29 \%$ & $36.39 \%$ & $36.15 \%$ \\
\hline Total lipid & $5.23 \%$ & $6.5 \%$ & $7.2 \%$ \\
\hline Fiber & $4.57 \%$ & $4.12 \%$ & $4.42 \%$ \\
\hline Moisture & $12.25 \%$ & $18.72 \%$ & $19.20 \%$ \\
\hline Ash & $13.71 \%$ & $15.95 \%$ & $16.12 \%$ \\
\hline
\end{tabular}

Table 4:- Effect of probiotic application on the growth performance of Litopenaeus vannamei with experimental feeds F1, F2 and F3 stocked at $45 \mathrm{pcs} / \mathrm{m}^{2}$

\begin{tabular}{|c|c|c|c|c|c|c|c|c|c|c|c|c|}
\hline \multirow{3}{*}{${ }_{\mathrm{D}} \mathrm{OC}$} & \multicolumn{4}{|c|}{ Commercial feed (F1) } & \multicolumn{4}{|c|}{ Animal based feed (F2) } & \multicolumn{4}{|c|}{ Plant based feed (F3) } \\
\hline & \multicolumn{2}{|c|}{$\begin{array}{c}\text { Without } \\
\text { Probiotics P1 }\end{array}$} & \multicolumn{2}{|c|}{$\begin{array}{c}\text { With } \\
\text { Probiotics P1p }\end{array}$} & \multicolumn{2}{|c|}{$\begin{array}{c}\text { Without } \\
\text { Probiotics P2 }\end{array}$} & \multicolumn{2}{|c|}{$\begin{array}{c}\text { With Probiotics } \\
\text { P2p }\end{array}$} & \multicolumn{2}{|c|}{$\begin{array}{c}\text { Without } \\
\text { Probiotics P3 }\end{array}$} & \multicolumn{2}{|c|}{$\begin{array}{c}\text { With Probiotics } \\
\text { P3p }\end{array}$} \\
\hline & $\begin{array}{l}\text { Avg } \\
\text { body } \\
\text { wt(g) }\end{array}$ & $\begin{array}{c}\text { Growt } \\
\text { h } \\
\text { incre } \\
\text { ment } \\
(\mathrm{g})\end{array}$ & $\begin{array}{l}\text { Avg } \\
\text { body } \\
\text { wt(g) }\end{array}$ & $\begin{array}{l}\text { Grow } \\
\text { th } \\
\text { incre } \\
\text { ment } \\
(\mathrm{g})\end{array}$ & $\begin{array}{l}\text { Avg } \\
\text { body } \\
\text { wt(g) }\end{array}$ & $\begin{array}{c}\text { Growth } \\
\text { increme } \\
\text { nt }(\mathrm{g})\end{array}$ & $\begin{array}{l}\text { Avg } \\
\text { body } \\
\text { wt(g) }\end{array}$ & $\begin{array}{l}\text { Growt } \\
\mathrm{h} \\
\text { increm } \\
\text { ent }(\mathrm{g})\end{array}$ & $\begin{array}{l}\text { Avg } \\
\text { body } \\
\mathrm{wt}(\mathrm{g})\end{array}$ & $\begin{array}{l}\text { Growt } \\
\mathrm{h} \\
\text { increm } \\
\text { ent }(\mathrm{g})\end{array}$ & $\begin{array}{l}\text { Avg } \\
\text { body } \\
\text { wt(g) }\end{array}$ & $\begin{array}{c}\text { Growt } \\
\mathrm{h} \\
\text { incre } \\
\text { ment } \\
(\mathrm{g})\end{array}$ \\
\hline $\begin{array}{l}\text { Initi } \\
\text { al wt }\end{array}$ & 0.67 & - & 0.67 & - & 0.67 & - & 0.67 & - & 0.67 & - & 0.67 & - \\
\hline 15 & 1.15 & 0.48 & 1.2 & 0.53 & 1.35 & 0.68 & 1.36 & 0.69 & 1.45 & 0.78 & 1.49 & 0.82 \\
\hline 30 & 2.23 & 1.08 & 2.47 & 1.27 & 3.58 & 2.23 & 3.62 & 2.26 & 2.57 & 1.12 & 2.65 & 1.16 \\
\hline 45 & 5.12 & 2.89 & 5.64 & 3.17 & 6.85 & 3.27 & 7.08 & 3.46 & 4.65 & 2.08 & 4.85 & 2.2 \\
\hline 60 & 8.54 & 3.42 & 9.44 & 3.8 & 12.27 & 5.42 & 13.07 & 5.99 & 7.95 & 3.3 & 8.64 & 3.79 \\
\hline 75 & 14.25 & 5.71 & 15.84 & 6.4 & 17.35 & 5.08 & 18.54 & 5.47 & 13.24 & 5.29 & 14.54 & 5.9 \\
\hline 90 & 19.85 & 5.6 & 22.58 & 6.74 & 23.15 & 5.8 & 24.74 & 6.2 & 18.94 & 5.7 & 20.64 & 6.1 \\
\hline
\end{tabular}




\begin{tabular}{|l|l|l|l|l|l|l|l|l|l|l|l|l|}
\hline 105 & 25.75 & 5.9 & 28.84 & 6.26 & 29.13 & 5.98 & 31.24 & 6.5 & 24.54 & 5.6 & 26.64 & 6.0 \\
\hline 120 & 32.25 & 6.5 & 35.45 & 6.61 & 35.33 & 6.2 & 38.14 & 6.9 & 30.44 & 5.9 & 33.24 & 6.6 \\
\hline
\end{tabular}

Table 5:- Average values of all the growth parameters under probiotic and non-probiotic treatment feed

\begin{tabular}{|c|c|c|c|c|c|c|}
\hline \multirow{2}{*}{ Parameter } & \multicolumn{2}{|c|}{ Feed F1 } & \multicolumn{2}{c|}{ Feed F2 } & \multicolumn{2}{c|}{ Feed F3 } \\
\cline { 2 - 7 } & P1 & P1p & P2 & P2p & P3 & P3p \\
\hline Initial Weight (g) & 0.67 & 0.67 & 0.67 & 0.67 & 0.67 & 0.67 \\
\hline Final Weight (g) & 32.25 & 35.45 & 35.33 & 38.14 & 30.44 & 33.24 \\
\hline \% Wt Gain & 4713.43 & 5191.04 & 5173.13 & 5592.53 & 4443.28 & 4861.19 \\
\hline SGR(\%day) & 3.22830 & 3.30715 & 3.30433 & 3.36811 & 3.18018 & 3.25351 \\
\hline ADG (g/pce/day) & 0.26875 & 0.29541 & 0.29441 & 0.31783 & 0.25366 & 0.277 \\
\hline FCR & 1.795 & 1.526 & 2.211 & 2.043 & 1.961 & 1.892 \\
\hline Survival\% & 73.4 & 84.5 & 69.8 & 80.4 & 67.5 & 79.8 \\
\hline Total Yield (Kg) & 4170.29 & 5409.05 & 3832.02 & 4793.85 & 3462.75 & 4524.66 \\
\hline Feed & 7487.21 & 8258.93 & 8473.92 & 9798.32 & 6792.96 & 8563.26 \\
consumption (Kg) & & & & & & \\
\hline
\end{tabular}

Table 6:- Effect of probiotic on selected immune parameters

\begin{tabular}{|c|c|c|c|c|c|c|}
\hline \multirow{2}{*}{$\begin{array}{c}\text { Immune } \\
\text { parameter }\end{array}$} & \multicolumn{2}{|c|}{ Feed F1 } & \multicolumn{2}{c|}{ Feed F2 } & \multicolumn{2}{c|}{ Feed F3 } \\
\cline { 2 - 7 } & P1 & P1p & P2 & P2p & P3 & P3p \\
\hline $\begin{array}{c}\text { Total Hemocyte } \\
\text { count (x106Cell/ml) }\end{array}$ & $8.5 \pm 0.3$ & $18.4 \pm 0.8$ & $7.3 \pm 0.4$ & $16.5 \pm 0.6$ & $7.2 \pm 0.5$ & $14.0 .4 \pm 0.6$ \\
\hline $\begin{array}{c}\text { PO activity } \\
\text { U/min/mg protein }\end{array}$ & $9.5 \pm 0.5$ & $16.4 \pm 0.3$ & $12.5 \pm 0.2$ & $15.4 \pm 0.4$ & $9.6 \pm 0.3$ & $11.5 \pm 0.6$ \\
\hline $\begin{array}{c}\text { Total } \\
\text { Hemolymph } \\
\text { Protein(mg/l) }\end{array}$ & $30.5 \pm 1.4$ & $39.4 \pm 2.6$ & $28.3 \pm 5.3$ & $42.2 \pm 5.3$ & $26.2 \pm 5.3$ & $37.5 \pm 4.2$ \\
\hline
\end{tabular}

According to Fuller, (1992) immunity may be improved by the probiotics in the following ways. Increasing macrophage activity, shown by the enhanced ability to microorganisms, increasing the production of systemic antibodies, usually of immunoglobulin and interferon (non-specific antiviral agent), increasing local antibodies, mucus surface at the gut wall. Krishna, (2009) stated that the use of probiotics in culture systems stimulates the growth of micro algae and improving survival rate also. This is quite evident in the present experiment.

In shrimp aquaculture, maintenance of water quality is essential for optimum growth and survival. The optimum temperature maintained in the present study was in between $28.18^{\circ} \mathrm{C}-31.03^{\circ} \mathrm{C}$. The transparency depends on the presence of phytoplankton, the optimum secchi disc reading should be $30-40 \mathrm{~cm}$ for shrimp culture. In the present study it was observed $20-45 \mathrm{~cm}$. The dissolved oxygen in the experimental ponds was maintained within the limits $3.9 \mathrm{mg} / \mathrm{l}-7.6 \mathrm{mg} / \mathrm{l}$ especially in the probiotics ponds. In the study the $\mathrm{pH}$ was maintained within the limit in the probiotics supplemented pond. Aeration was maintained throughout the culture ponds to avoid the decaying process. The level of ammonia was observed at $0.32 \mathrm{mg} / \mathrm{l}$ in the probiotics treated ponds and slightly higher levels were noticed in the control ponds. In addition, growth and survival of the Litopenaeus vannamei was significant in the probiotics treated ponds $(\mathrm{P} \leq 0.05 / \mathrm{P}<0.05)$. Better survival percentage of $84.5,80.40$ and 79.80 percent was recorded in the probiotics treated ponds whereas in non probiotics it is 73.4, 69.8 and 67.5 only. Rengipat et al., (2000) observed that the increased rate of survival of shrimp Penaeus monodon after feeding with probiotics Bacillus for 90 days. Lipton et al., (2006) stated that the shrimp farms observed a rapid increase in microbial load after application of probiotics. Probiotics have multiple mechanisms of action to inhibit pathogens which include competitive exclusion, production of substances that inhibit growth of opportunistic pathogens (antagonism), stimulation of the immune response, antiviral effects, increase of digestive function through production of enzymes, improved nutrition by providing essential nutrients, and improved water quality (Balcázar, 2002; Balcázar et al., 2006; Farzanfar, 2006). Krishna et al., (2009) and Alokesh kumar ghosh et al., (2016) stated that the probiotics enhanced survival and growth of aquatic organisms and also enhanced immune response.

Crustacean defence system mainly consists of cellular and humeral components (Ratcliff et al.,1985). The cellular reactions include phagocytosis and nodule formation (Soderhall and Cerenius, 1992; Roch, 1999). Humoral 
reactions compromise of Phenoloxidase system (Soderhall et al., 1996), antimicrobial peptides (Destoumieux et al., 1997) and coagulation mechanisms (Montano-Perez et al., 1999). Under the culture conditions, wide range of stresses caused by various adverse environmental factors damage the host defence system resulting in an increased susceptibility to infections (Perazzolo et al., 2002).

The results of the present study have revealed that the total haemocyte count of the shrimp Litopenaeus vannamei fed with probiotic supplemented diet was higher than shrimp from the non probiotic fed shrimp. Total haemolymph protein was also higher in probiotics fed to Litopenaeus vannamei compared to without probiotic fed shrimp. Some studies have reported that alterations in the PO enzyme activity in shrimp treated with probiotics such as in Litopenaeus vannamei (Gullin et al., 2004) and Penaeus monodon (Rengpipate et al., 2000). The immune parameters of the shrimp were given in Table 6 .

The research on use of probiotics in the aquatic animals is increasing with the demand for environment friendly aquaculture (Gatesoupe, 1999). The benefits of the supplements include improvement of feed value, enzymatic contribution to digestion, inhibition of pathogenic microorganisms as anti-mutagenic and anti-carcinogenic activity, growth promoting factors and immune response (Sharma and Bhukar, 2000; Vershurere et al., 2000; Ziaei-Nejad et al., 2006; Wang et al., 2005; Wang and Xu, 2006; Wang, 2007). In the present study our results also show that probiotics enhance the production of Litopenaeus vannamei.

\section{References:-}

1. A.P.H.A (American Public Health Association), 1985. Standard Methods for the Examination of Water and Wastewater.

2. Alokesh Kumar Ghosh, Joyanta Bir, Md. Abul Kalam Azad, Abul Farah Md. Hasanuzzaman, Md. Sanaul Islam, Khandaker Anisul Huq, 2016. Impact of commercial probiotics application on growth andproduction of giant fresh water prawn (Macrobrachium Rosenbergii DeMan, 1879). Elsevier, 4: 112-117.

3. Balcazar J L, 2002. Uso de probióticos en acuicultura: Aspectos generales. CIVA (http://www.civa2002.org): 877-881.

4. Balcazar J L, De Blas I, Ruiz Zarzuela I, Cunningham D, Vendrell D and Múzquiz J L 2006. The role of probiotics in aquaculture. Vet. Microbiol, 114:173-186.

5. Balcazar. J. L, de Blas. I, Ruiz-Zarzuela. I, Cunningham. D, Vendrell. D, Muzquiz. J.L. 2006. The role of probiotics in aquaculture. Vet. Microbiol. 114(3-4): 173-186.

6. Biomin, 2009. Evaluation of vibrio with a multi-species probiotics in shrimp aquaculture. Article by De Elisabeth Mayer, Technical manager, BIOMINBird, J.N. 1997. Vitamin supplements revised. Feed Milling International, March, pp: 10-13.

7. Boyd, C.E. 1984. Water Quality in Warm Fish ponds. Alabama Agriculture Experiment Station, Auburn Unive., Auburn, Alabama, U.S.A.

8. Boyd, C.E. 1990. Water Quality in ponds for aquaculture. Agriculture Experiment Station, Auburn Univ., Alabama, U.S.A: 482.

9. Boyd. E.F and Massaut. L. 1999. Risks associated with the use of chemicals in pond aquaculture. Aquacult. Eng. 20: 113-132.

10. Decamp O, Moriarty DJW and Lavens P. 2008; Probiotics in shrimp culture: Review of field data from Asia and Latin America. Aquacult. Res. 39:334-338.

11. FAO, 2007. Food and Agriculture Organization of United Nations. The state of the World Fisheries and Aquaculture (SOFIA) 2006 FAO Fisheries and Aquaculture Department. Rome, Italy. 180pp.

12. Farzanfar, A. 2006. The use of Probotics in shrimp Aquaculture. FEMS. Imm. A Med. Microb. 48: 149-158.

13. Fuller. R, 1992. History and development of probiotics . In: Fuller. R (Ed.), Probiotics: The scientific Basis, vol. 232. Chapman \& Hall, London, pp.1-18.

14. Fuller. R. 1989, Probiotics in man and animals. Journal of Applied Bacteriology, 66: 365-378.

15. Gatesoupe, F.J.1999. The use of probiotics in Aquaculture. Aquaculture, v. 180, p. 147-165,Gautier, D. M. Bastidas, L. Aragon, W.Urango, C.Ramos, S. Garcia, J. A. Pastrana and F. Nwemark, 2001. The relative importance of natural food and pelleted feed in the gut content of Litopenaeus vannamei raised in semiintensive ponds-role of benthic diatoms, Aquaculture 2001. The Annual International Conference and Exhibition of the World Aquaculture Society Book of Abstracts, Jan 21-25, 2001. Orlando, Florida, USA p: 247.

16. Gullin, M., Thompson, F. Rodriguez, J. 2004. Selection of probiotics bacteria and study of their immunostimulatory effect in Peneaus vannamei, Aquacult Int. 18: 921-933. 
17. Irianto, A and Austin. B, 2002. Probiotics in aquaculture. J. Fish Diseases. 52: 633-642.

18. Karthik R, Angelin C Pushpam, Yashika Chelvan and M. C. Vanitha, 2016. Efficacy of probiotic and nitrifier bacterial consortium for the enhancement of Litopenaeus vannamei aquaculture, International Journal of Veterinary Science and Research, 2(1): 001-006.

19. Krishna. P.V, Rama rao. N, A.V.V.S and Sharma. S.V. 2009. Probiotics use in biological systems- A Review J. Pharma. Tech and Res. 1(1): 1-16.

20. Lipton. A.P, Jose. J. J, Subash, S.K and Udayakumar. A, 2006. Increased production of shrimp Penaeus monodon in farm condition by incorporating marine natural products and probiotics - A case, p-35. Abstracts. National seminar on Biomedicine in Aquaculture. March 17-18. Centre for Marine Science and technology. Tamil Nadu.

21. Marrifiel D. L, Dimitroglou. A, Davis. J.S, Baker TMR, Bogwald J, Castex. M, Ringo. E, 2010. The current status and future focus of probiotics and probiotics applications for salmonoids. Aquaculture 302: 1-18.

22. Rengpipat.S, Rukpratanporn. S, Piyatiratitivorakul, 2000. Immunity enhancement in black tiger shrimp (Penaeus monodon) by a probiont bacterium (Bacillus S11), Aquaculture, v. 191, p: 271-288.

23. Sharma, O.P., Bhukhar, S.K.S. 2000. Effect of Aquazyn-TM-1000, a probiotics on water quality and growth of Cyprinus carpio var. communis(L). Indian J. Fish. 47, 209-213.

24. Verchurere, L., Rombaut, G., Sorgeloss. P., Verstraete, W. 2000. Probiotics bacteria as biological control agents in aquaculture. J. Microbiol. Mol. Biol. Rev. 64: 655-671.

25. Vine. N.G, Leukes. W. D, Kaiser. H., 2006. Probiotics in marine larviculture. FEMS Microbiol. Rev. 30: 404427.

26. Wang, Y.B., Xu, Z.R, 2006. Effect of probiotics for common carp (Cyprinus carpio) based on growth performance and digestive enzyme activities. Animal feed Sci. Technol. 127: 283-292.

27. Wang. L. U and Chen. J. C. 2005. The immune response of White shrimp Litopenaeus vannamei and its susceptibility to vibrio alginolyticus at different salinities levels. Fish and Shell fish immunology. 18: 269-178.

28. Wang. Y. B. 2007. Effect of probiotics on growth performance and digestive enzyme activity of shrimp Penaeus vannamei. Aquaculture 269: 259-264.

29. Wurmann C, Madrid RM, Brugger AM. Shrimp farming in Latin America: Current status, opportunities, challenges and strategies for sustainable development. Aquactic. Econ. Manag. 2004; 8:117-141.

30. Ziaei-Nejad, S., Rezaei, M.H., Takami, G.A., Lovett, D.L., Mirvaghefi, A.R., Shankouri, M. 2006. The effect of Bacillus spp. Bacteria used as probiotics on digestive enzyme activity, survival and growth in the Indian white shrimp Fenneropenaeus indicus, Aquacult, 252: 516-524. 